\title{
MARKETING STRATEGY THROUGH COVID-19 PREVENTION MESSAGES IN GOJEK ADVERTISING “J3K”
}

\author{
Debi Nur Hanifah \\ IAIN Ponorogo \\ debynurhanifah@gmail.com \\ Dimas Suarli \\ dimassuarli@gmail.com \\ Yuvelia Cahya Indrawan \\ yuveliacahyaindrawan@gmail.com
}

\begin{abstract}
Advertising is a fundamental part of one of the functions of marketing strategy with the aim of not only informing the public but also aimed at influencing someone about the image of a product. The Covid-19 prevention content that is being discussed is an opportunity for the Gojek company to do marketing. Through YouTube media, the Gojek company aired the ad "J3K" Take care of health, maintain cleanliness and maintain security as an effort to prevent the spread of Covid-19. This study will reveal marketing strategies through the message of preventing Covid-19 in the Gojek "J3K" advertisement. This research uses qualitative research methods through analytical descriptive exposure. The implicit marketing strategy in the Gojek "J3K" advertisement is analyzed using semiotics from Ferdinand De Saussure. In the analysis, produced a sign (signifier), a marker (signified) and a sign (sign). The signifier in the Gojek "J3K" advertisement is recorded visually and audio in the advertisement so that there are similarities in the meaning of the sign. After knowing the signifier, an agreement will be obtained on the concept of sign meaning in the form of a signified.
\end{abstract}

Keywords: Advertising, Marketing Strategy, Covid-19, Semiotics

\section{INTRODUCTION}

This research is directed to find out more about the marketing efforts carried out by the Gojek company in the "J3K" advertisement for Keeping Health, Keeping Clean and Keeping Security wrapped together with information on Covid-19 prevention. It is known that Covid-19 entered Indonesia at the beginning of 2020, precisely after the Indonesian government released an official statement regarding 2 cases of 
QAULAN, Vol. 2, No.2, Desember 2021

Debi Nur Hanifah, et. al., Marketing Strategy....

positive Covid-19 patients on March 2, 2020.1 The collaboration between the central government and regional governments in producing policies related to preventing the spread of Covid-19 is expected to be able to reduce the rate of Covid-19 infection in Indonesia. The accumulated data reported by the COVID-19 Handling Task Force shows that the percentage of Covid-19 cases in Indonesia is still high from time to time. ${ }^{2}$ Responding to the outbreak of Covid-19, the government continues to aggressively disseminate the appeal for the prevention of Covid-19 to the public through various media.

In KPI's circular letter number 183/K/KPI/31.2/03/2020, broadcasting institutions as one of the information providers fully support the socialization of Covid-19 prevention through broadcast programs. ${ }^{3}$ Updates on the news regarding the prevention of Covid-19 through the media, one of which is television and YouTube, have caused this topic to be discussed by the public. It is this kind of problem that Gojek uses its dragons as a marketing tactic for its products in the midst of the Covid-19 outbreak. Advertisements that are neatly packaged with Covid-19 prevention orders are the right effort to introduce the existence of Gojek's company products to consumers. It is known that the Covid-19 pandemic has caused several companies to go out of business, the rest of the industry is required to stay alert to fight against conditions that are increasingly difficult to predict. Gojek's monitoring of company stability is not only focused on presenting the advantages of a product, but also taking product introduction actions through advertising promotions by adjusting the current situation.

According to Kotler and Armstrong, advertising is a form of presenting ideas through goods or services in a non-personal manner that involves certain sponsors so that it requires a commission as payment. ${ }^{4}$ Basically, the purpose of a company doing advertising is to change public perception according to what the advertiser company wants. Advertising is able to spearhead the success of increasing product sales because of its persuasive nature. Through ad impressions, the message

${ }^{1}$ See in www.kompas.com (Accsessed at 14 October 2020, 14.54).

${ }^{2}$ See in www.covid19.go.id (Accsessed at 04 October 2020, 21.30).

${ }^{3}$ See in www.kpi.go.id (Accsessed at 04 October, 22.00).

${ }^{4}$ Philip Kotler and Garry Amstrong, Principles of Marketing (New Jersey: Pearson Education Limited, 2012), p. 454. 
QAULAN, Vol. 2, No.2, Desember 2021

Debi Nur Hanifah, et. al., Marketing Strategy....

conveyed is described as attractive as possible with the aim of luring customers to make purchasing power to use a product. The communication process model (Hierarchy of Effects) in advertising which contains the process from being unaware of a product to the act of purchasing a product by consumers is an important part that must be emphasized in the delivery of advertising content. The demand made by consumers for a product is a response to the disclosure of the company's offerings which will ultimately affect the company's sales profit.

As with technology, advertisements are urged to present content according to the times. Advertising users continue to increase every year until in the end many companies are competing to introduce a product through advertising with the best quality. Ad serving itself can be found in two lines, namely through the top line (Above the Line) and the bottom line (Below the Line). ${ }^{5}$ The top line (Above the Line) is the main media carried out in advertising activities such as television, radio and others. While the bottom line (Below the Line) is the supporting media that can be found in brochures, posters and pamphlets. Both lines become equally important depending on the intended use of the advertiser company.

Advertisements made by the Gojek company mostly use the top line (Above the Line) to target a wider audience. Advertising is a representation of the image of a product. Gojek's advertising slogan "J3K" in every service faces a period of change in a safe and fun way by always using Gojek products that are displayed, becoming the image of Gojek's company with a clear Covid-19 prevention message that is broadcast according to the appeal from the government. Gojek invites the public to actively, together fight Covid-19 based on health protocols by using products that have been provided by the Gojek company. Products that are trying to be shown through Gojek "J3K" advertisements include GoMed, GoFood, GoMart, GoPay, GoRide, and GoCar. In the advertisement, Gojek ensures that Gojek products are able to provide better services to answer the needs of their consumers in the midst of the Covid-19 pandemic.

\footnotetext{
${ }^{5}$ Ambar Lukitaningsih, "Iklan yang Efektif sebagai Strategi Komunikasi Pemasaran," Jurnal Ekonomi dan Kewirausahaan, Vol. 03, No. 12 (Oktober, 2018), p. 118.
} 
QAULAN, Vol. 2, No.2, Desember 2021

Debi Nur Hanifah, et. al., Marketing Strategy....

In addition, government policies in tackling the spread of Covid-19 force the public to carry out most of their activities at home, such as studying, working, and praying. The emphasis on postponement until the cancellation of activities that bring large crowds is an anticipatory step that must be obeyed by all parties. The normal daily activities carried out every day to be spent outside the home are slowly shifted to the virtual world in order to reduce face-to-face interaction. Public activities carried out by the public when they are at home, as now, most of their time is spent watching. This is a reference for how an advertisement must be able to display its best quality to prevent boredom from the audience.

The innovation that the Gojek company continues to develop through creative advertising shows is a form of commitment to maintaining health in the Gojek ecosystem, from driver partners to customer convenience. The brand image strategy carried out by the Gojek company is to ensure that Gojek products remain the best online application choices and are able to serve consumers in the midst of the Covid-19 pandemic. The guarantee for the health and safety of the Gojek company is carried out in various ways, one of which is the provision of barriers in GoRide and GoCar to the mandatory use of shields for drivers.

This study focuses on research related to marketing strategies that are packaged through the Covid-19 prevention message in the Gojek "J3K" advertisement. Several other research literatures conducted research by taking from the point of view of the problem the influence of Gojek's advertising on consumer purchasing power. Considering that the Gojek "J3K" advertisement that was taken in this study was only launched by the Gojek company in August and coincided with the Covid-19 pandemic, so this research is expected to be able to raise something that has not been analyzed by previous researchers. The wrapping of the Covid-19 prevention message brought by the Gojek company in the Gojek "J3K" advertisement also added to the interest of researchers in conducting research.

In conducting the research, the researcher used semiotic analysis from Ferdinand De Saussure. In Ferdinand De Saussure's semiotic analysis, it was found that the analytical method used two main things, namely the signifier and signified parts. Signifier (signifier) and signified (signified) composed of external reality that 
QAULAN, Vol. 2, No.2, Desember 2021

Debi Nur Hanifah, et. al., Marketing Strategy....

describes the meaning. The Gojek "J3K" advertisement is analyzed for each image using Ferdinand De Saussure's theory so that it is able to dismantle the meaning of the marketing strategy contained in the Gojek "J3K" advertisement in the Covid-19 prevention message.

\section{MARKETING}

Marketing is a concept related to mental attitudes and ways of thinking about selling something, both products and ideas. ${ }^{6}$ Broadly speaking, marketing is a social and managerial process of obtaining what is needed and wanted through the creation and exchange of value with others. ${ }^{7}$ Marketing is closely related to the marketing mix in the form of elements of the product (product), price (price), place of distribution (place) and promotion (promotion). ${ }^{8}$ The 4P marketing mix will give birth to a cohesive marketing strategy to support sales.

Non-personal communication activities related to organizations and products that are transmitted to the target mass through media that are charged with payment are the substance of advertising. ${ }^{9}$ Advertising through various media is a form of Integrated Marketing Communications. Structurally, advertising contains signs as a picture of the concept and meaning that is material in an image or illustration in constructing social reality. Sign elements can be found in images (objects), supporting contexts for images (context) and writing (text) so that they can describe both visible meaning (denotative) and hidden understanding (connotative). ${ }^{10}$

${ }^{6}$ Rhenald Kasali, Membidik Pasar Indonesia: Segmentasi, Targeting, dan Positioning (Jakarta: PT Gramedia Pustaka Utama, 2001), p. 51.

7 Philip Kotler, Manajemen Pemasaran, Edisi 13 (Jakarta: Erlangga, 2009), p. 6.

8 Morissan, Periklanan: Komunikasi Pemasaran Terpadu (Jakarta: Prenadamedia Group, 2010), p. 5.

${ }_{9}^{9}$ Komang Ayu Pradnya Indrawati, Nyoman Sudiarta, Wayan Suardana, "Efektifitas Iklan melalui Media Sosial Facebook dan Instagram sebagai Salah Satu Strategi Pemasaran di Krisna Oleh-Oleh Bali," Jurnal Analisis Pariwisata, Vol. 17 No. 2 (2017), p. 79.

10 Yasraf Amir Piliang, Hipersemiotika: Tafsir Cultural Studies atas Matinya Makna (Bandung: Jalasutra: 2003), p. 280. 
QAULAN, Vol. 2, No.2, Desember 2021

Debi Nur Hanifah, et. al., Marketing Strategy....

According to Ferdinand de Saussure, the science that explores the meaning of signs on part of social life is semiotics. The convention of interpretation of meaning for Ferdinand relates to 3 things, including arbitrary language signs (arbitrary), linear markers and language signs themselves in the form of language (sign), signifier (signifier) and signified (signified). The semiology expressed is based on the rules or social codes that apply in society so that collective meaning is obtained. ${ }^{11}$

\section{RESEARCH METHODS}

This study uses qualitative research methods through analytical descriptive exposure. Qualitative research methods are used in natural object research with the researcher as the key instrument in collecting data by triangulation (combined) so that the research results emphasize meaning rather than generalization. ${ }^{12}$ The data analysis technique used is Ferdinand De Saussure's semiotic analysis with an interpretive approach. A critical paradigm is needed in seeing the representation of knowledge conveyed in advertising signs. In Ferdinand's view, there are 4 things, namely signifier and signified, synchrony and diachrony, language (langue) and speech (parole) and syntagmatic and paradigmatic relationships. ${ }^{13}$

Sources of data collected are the results of library research through books, journals, and other supporting references as well as public documentation studies from television and the internet in obtaining photos and videos according to the research to be studied. The results of the data obtained are primary data in the form of the Gojek "J3K" advertisement which aired on August 10, 2020 with a duration of 1 minute and secondary data sources in the form of documentation and literature that support the research. After the data is collected and then analyzed to produce the validity of the research results.

${ }^{11}$ Ibid., p. 256.

${ }^{12}$ Sugiyono, Metode Penelitian Kuantitatif, Kualitatif, dan R \& D (Bandung: Alfabeta, 2016), p. 9.

${ }^{13}$ Alex Sobur, Analisis Teks Media: Suatu Pengantar untuk Analisis Wacana, Analisis Semiotika dan Analisis Framing (Bandung: Remadja Karya, 2001), p. 46-54. 
QAULAN, Vol. 2, No.2, Desember 2021

Debi Nur Hanifah, et. al., Marketing Strategy....

\section{THE REALITY OF NEW MARKETING STRATEGIES AS A PREVENTION OF COVID-} 19

In achieving target consumers, the company introduces products through marketing channels. The marketing channel itself is divided into 3 roads, namely communication channels, distribution channels and service channels. ${ }^{14}$ Marketing channels connect producers with consumers who adapt to the marketing environment. The development of technology as an element of the marketing demographic environment indicates that the market can no longer be equated with the past. In maintaining existence, the company must respond swiftly to various changes in the reality of new marketing strategies.

Industry convergence creates new capabilities for companies to align with technological developments. The Gojek company through mobile marketing maximizes the introduction of internal communication using the internet. In the marketing strategy that is implemented, there are 3 parts that are considered crucial, namely planning, implementation and control. ${ }^{15}$

The selection of the right media in the Gojek product advertising campaign with Covid-19 prevention packaging makes Gojek's products easily known by consumers. In addressing the ambition of the company's progress, Gojek utilizes the YouTube platform in marketing advertisements. The features that YouTube continues to develop make it popular with various groups, especially during the majority of activities at home. Gojek's ad "J3K" puts a message on preventing Covid19 on YouTube as a marketing strategy. In its manufacture, the Gojek company does planning by analyzing SWOT, namely strengths, weaknesses, opportunities and threats. ${ }^{16}$ Implementation actions through YouTube panels have a stronger appeal

14 Ismawati Doembana, Abdul Rahmat, Muhammad Farhan, Buku Ajar: Manajemen dan Strategi Komunikasi Pemasaran (Yogyakarta: Zahir Publishing, 2017), p. 68-69.

15 Onny Fitriana Sitorus, Novelia Utami, Buku Ajar: Strategi Promosi Pemasaran (Universitas Muhammadiyah Prof. DR. HAMKA: Fakultas Keguruan dan Ilmu Pendidikan, 2017), p. 27.

16 Fahmi Fadlillah Syaiful, Elihami Elihami, "Penerapan Analisis SWOT terhadap Strategi Pemasaran Usaha Minuman Kamsia Boba Milik Abdullah di Tengah Pandemi Covid19 di Kabupaten Bangkalan," Jurnal Edukasi NonFormal, Vol. 1 No. 2 (2017), p. 346-347. 
with a wider reach. The viral Covid-19 prevention content and the cost of advertising on YouTube have not escaped the attention of the Gojek company in analyzing marketing opportunities.

Copy (content) of the advertisement displayed by the Gojek company to inform the reason for the excess of the product with other products delivered in a different style. Broadly speaking, in conveying advertising content, several things need to be considered to attract consumers' interest, including: (1) footage of individual or group lives, (2) individual lifestyles, (3) product fantasies, (4) mood. or imagery around the product, (5) music to liven up the message, (6) personality symbols to create a character that personifies the product, (7) showcase the company's expertise and experience in producing products, (8) scientific evidence of product excellence, $(9)$ testimonies of famous people. ${ }^{17}$

\section{ADVERTISING ORIENTATION IN GOJEK “J3K” MARKETING COMMUNICATIONS}

This section has an essential nature in research by examining the main focus in the form of the Gojek "J3K" advertisement uploaded on the Gojek official Youtube site.18 The discussion concerns three aspects, namely the signifier, the signified and the sign. The signifier in the Gojek "J3K" advertisement is recorded visually and audio in the advertisement so that there are similarities in the meaning of the sign. After knowing the signifier, an agreement will be obtained on the meaning of the sign in the form of a signified.

Scene 1

\begin{tabular}{|l|l|}
\hline \multicolumn{2}{|c|}{ (sign) } \\
\hline The importance of maintaining the quality of life with Gojek J3K \\
\hline \multicolumn{2}{|c|}{ (signifier) } \\
$\begin{array}{l}\text { A man is worried about the } \\
\text { condition of his face that does not } \\
\text { fit like most other people's faces. } \\
\text { Then he is seen doing physical }\end{array}$ \\
\hline
\end{tabular}

17 Onny, p. 87.

18 See in www.youtube.com (Accsessed at 01 October 2020, 09.32). 


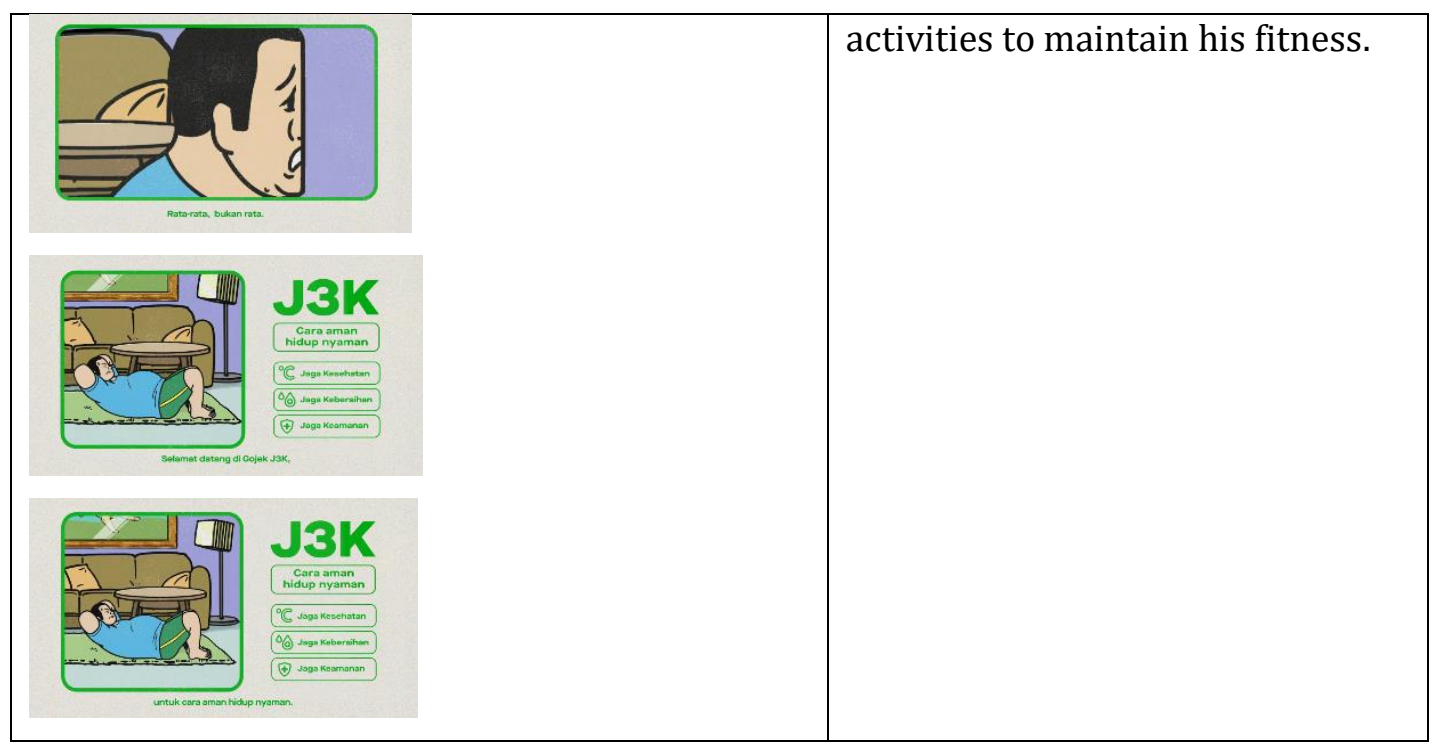

The first scene construction that wants to be voiced is "J3K" a comfortable way of living comfortably through an illustration of a man's anxiety and distress. Almost all activities during the Covid-19 pandemic were diverted to home, so it was not uncommon for someone to feel uncomfortable in living their daily lives. By staying at home, Gojek is always present and trying to be with consumers. Armed with the alternative "J3K" principle of maintaining health, maintaining cleanliness, maintaining security, which was launched by the Gojek company, it is expected to be the first choice for the public, so that they can live a good life amid Covid-19.

Scene 2

\begin{tabular}{|c|c|}
\hline \\
\hline \multicolumn{2}{|c|}{ Maintain health by regularly taking vitamins } \\
\hline (signifier) & (signified) \\
\hline 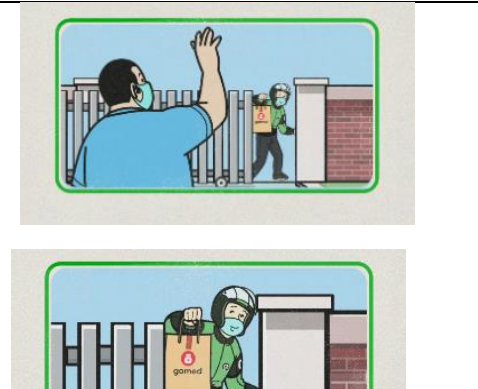 & $\begin{array}{l}\text { A man who is ordering vitamins } \\
\text { through the GoMed service on } \\
\text { Gojek. Orders are delivered } \\
\text { according to health protocols } \\
\text { while still wearing masks and } \\
\text { keeping a distance. }\end{array}$ \\
\hline
\end{tabular}




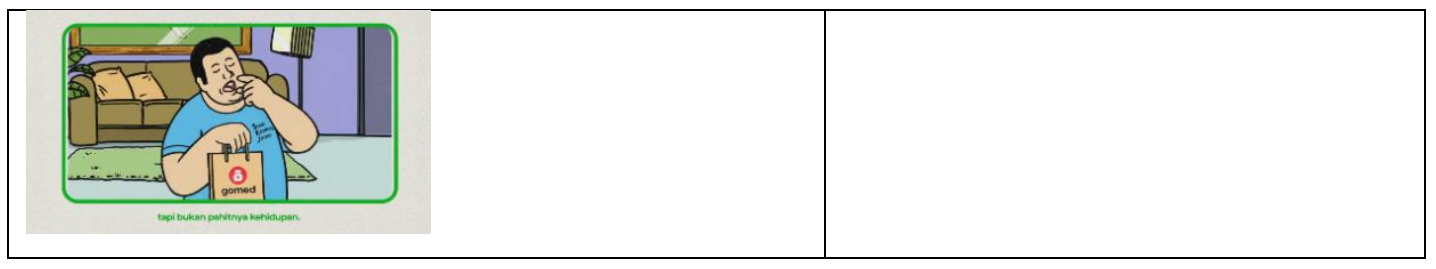

Maintaining body intake during a pandemic is a must. Good body condition can reduce the level of susceptibility to viral and bacterial infections and other diseases. In this second scene, Gojek instills in the masses the memory that they have the GoMed feature as an answer to their anxiety about meeting stamina during Covid-19. With the GoMed service, customers can now make an appointment to do a Covid-19 rapid test, besides being able to buy vitamins, medicines, make face-to-face appointments with doctors and others related to health services, as well as cooperate with Halodoc services. Through the visualization of GoMed in advertisements, the Gojek company is ready to serve consumers in terms of fulfilling medical needs such as purchasing medicines and vitamins.

\section{Scene 3}

\begin{tabular}{|c|c|}
\hline \\
\hline \multicolumn{2}{|c|}{ Ease of fulfilling the necessities of life with online purchases. } \\
\hline (signifier) & (signified) \\
\hline & $\begin{array}{l}\text { A man looks thirsty after } \\
\text { swallowing medicine. He } \\
\text { immediately took the Smartphone } \\
\text { to open the GoMart feature and } \\
\text { then chose the option to order } \\
\text { food and drinks to order mineral } \\
\text { water. Orders that have been } \\
\text { received are immediately } \\
\text { prepared and delivered by the } \\
\text { driver according to the place } \\
\text { desired by the customer. In } \\
\text { submitting orders, drivers try to }\end{array}$ \\
\hline
\end{tabular}




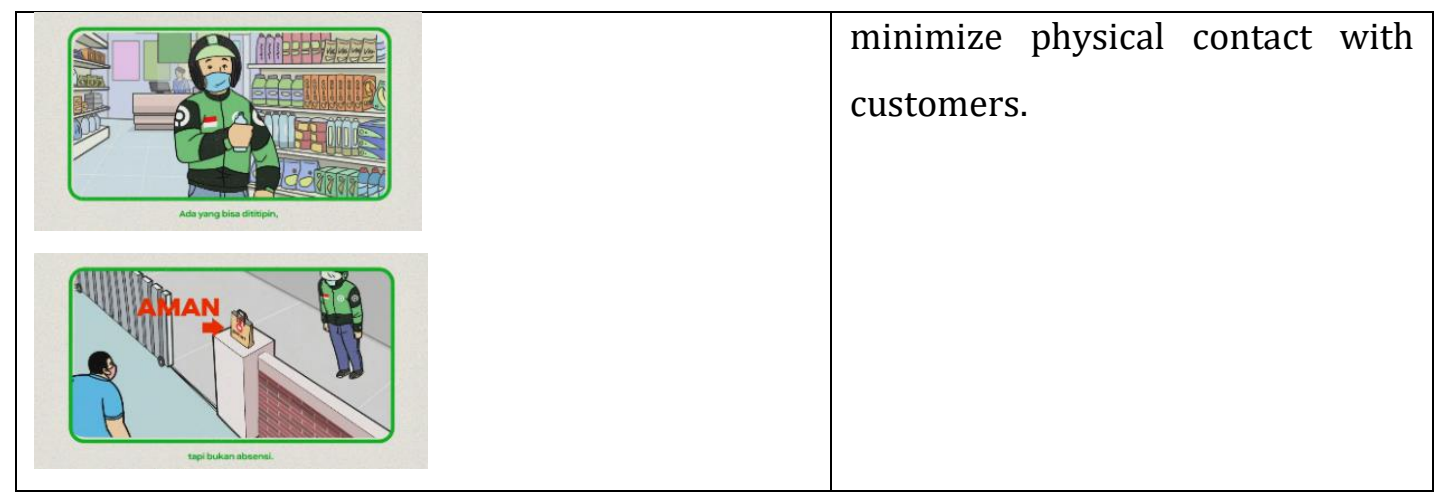

The third scene reflects the easy access to purchasing necessities via online. In the Covid-19 situation, many people have finally decided to switch from direct purchases to online. The substance inserted in the illustration, namely Gojek is a product that the public can rely on, as can be seen from GoMart drivers ensuring that the ordered goods land perfectly according to health protocols by always wearing masks and minimizing physical contact with customers. So that customers more easily do not need to choose or prepare their own goods. This is included in the optimized security guard procedures for GoMart services.

Scene 4

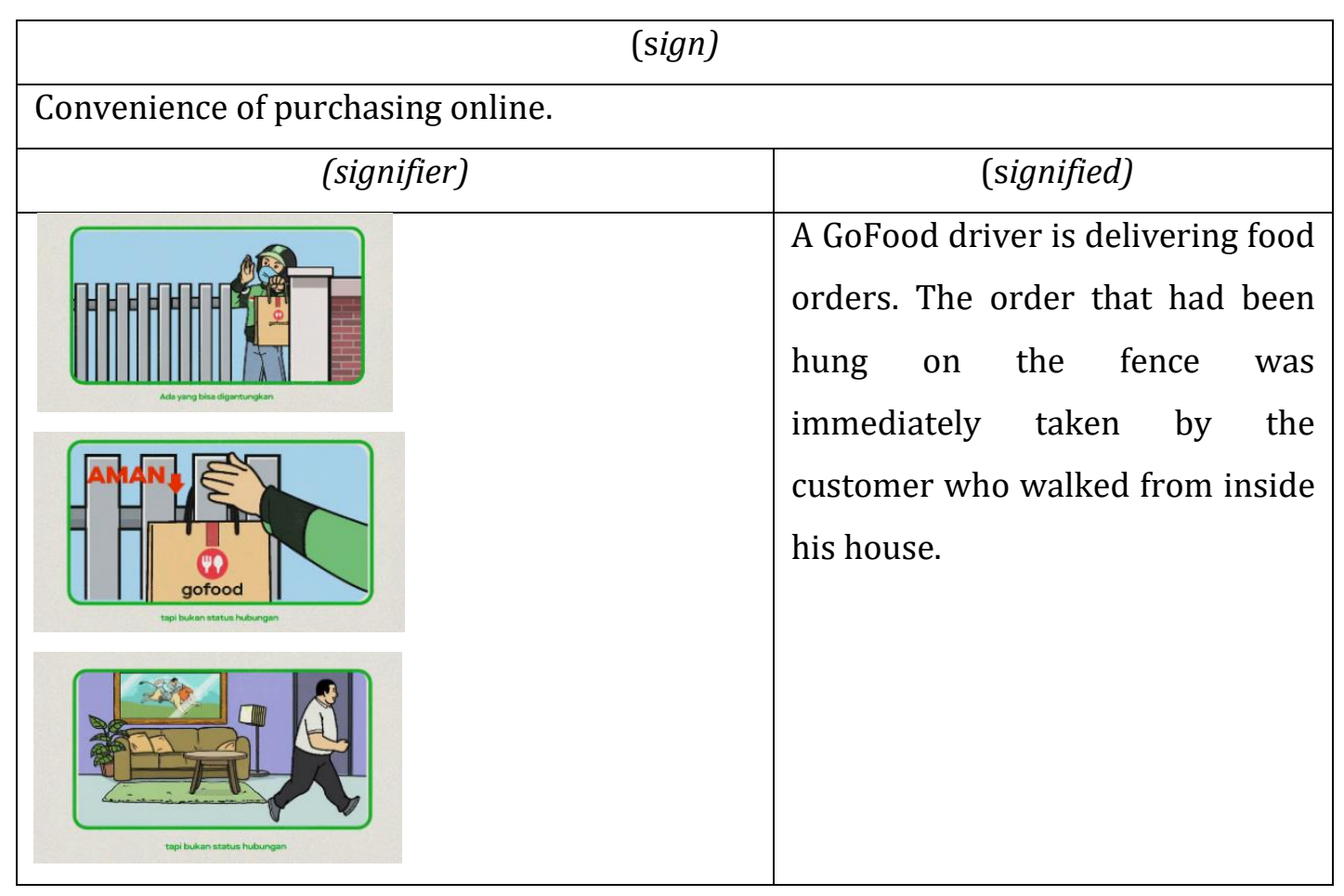




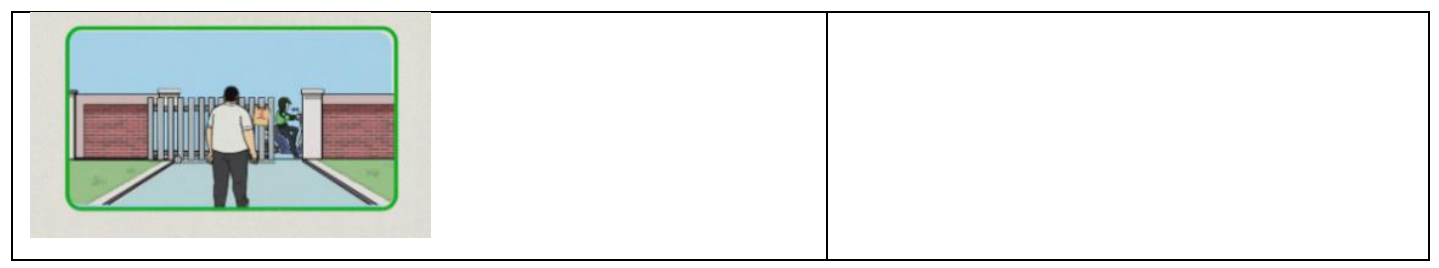

The visualization of the GoFood order box hanging on the fence in the fourth scene convinces the audience that orders can be accepted flexibly but still pay attention to safety and cleanliness. Keeping clean in the J3K initiative is to ensure the cleanliness of the ecosystem. GoFood partners are encouraged to provide sinks and hand sanitizers for driver partners and keep food hygienic. So that the customer does not need to feel anxious that there will be physical contact with foreign drivers directly so that the customer feels comfortable and safe with the order that has been ordered. GoFood shows the convenience of the customer in the scene as a form of positive impression of GoFood service.

\section{Scene 5}

\begin{tabular}{|l|l|}
\hline \multicolumn{2}{|c|}{ (sign) } \\
\hline Security makes happiness. & $\begin{array}{l}\text { A man was opening a food order } \\
\text { from the previous scene. There } \\
\text { was a happy expression after the } \\
\text { man opened the safety seal in the } \\
\text { food box. }\end{array}$ \\
\hline
\end{tabular}

In the fifth scene, Gojek informs the masses of the security guarantees carried out in GoFood, namely by providing a safety seal so that food is not contaminated by bacteria, viruses or other parasites. Delivery of GoFood orders by GoJek driver partners can be done without physical contact, referring to the call for physical distancing. The security carried out by Gojek makes its own happiness for customers, as a result Gojek will become the main destination for those who want to order food. 
QAULAN, Vol. 2, No.2, Desember 2021

Debi Nur Hanifah, et. al., Marketing Strategy....

Scene 6

\begin{tabular}{|l|l|}
\hline \multicolumn{2}{|c|}{ (sign) } \\
\hline Forms of care can be done anywhere.
\end{tabular}

Jaga Safety is a GoJek program in providing protection for mutual security.

Following the outbreak of Covid-19, the Gojek company through GoCar continues to innovate to support the safety of both driver partners and passengers by providing information on driver partners' body temperatures and the disinfection status of their vehicles that can be seen by customers in the application as well as providing protective bulkheads and the obligation to wear masks. The form of concern shown by GoCar makes passengers not need to worry when traveling using GoCar.

\section{Scene 7}

\begin{tabular}{|c|c|}
\hline \multicolumn{2}{|c|}{ (sign) } \\
\hline Ease of payment through GoP & \\
\hline (signifier) & (signified) \\
\hline $1 \quad 1000$ & $\begin{array}{l}\text { Seen a man is entering the shop to } \\
\text { buy a helmet. At the time of } \\
\text { payment, he took out his wallet } \\
\text { but found it was full of bacteria. } \\
\text { Then the employee offers }\end{array}$ \\
\hline
\end{tabular}




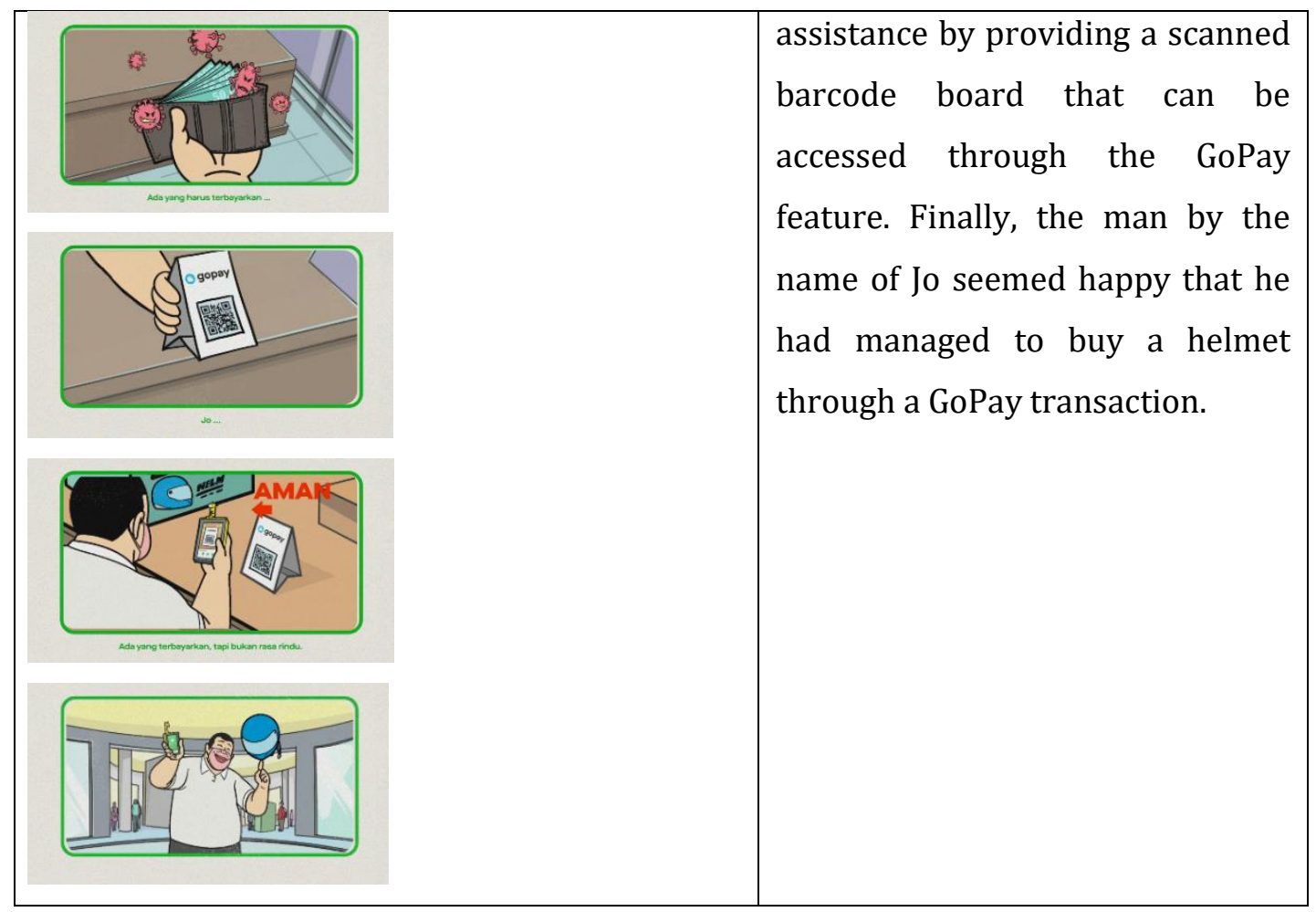

GoPay is a virtual wallet to store GoJek credits that can be used to pay for transactions related to services in the GoJek application. In GoPay there are many features including, GoPulsa, GoBills, GoPay transfers, GoPay cash withdrawals. The GoPay feature in this seventh scene provides easy access and security for a person during direct or indirect transactions. Manual payment instruments (money) are always touched by each owner and the cycle rotates as the owner of the money changes so that it has a high risk of transmitting bacteria, viruses and other parasites. GoPay is here as a solution so that GoPay users are more flexible in conducting transactions during the current pandemic.

Scene 8

\begin{tabular}{|l|l|}
\hline \multicolumn{2}{|c|}{ (sign) } \\
\hline Keeping yourself safe is also protecting the safety of others. \\
\hline \multicolumn{2}{|c|}{ (signifier) } \\
\hline
\end{tabular}




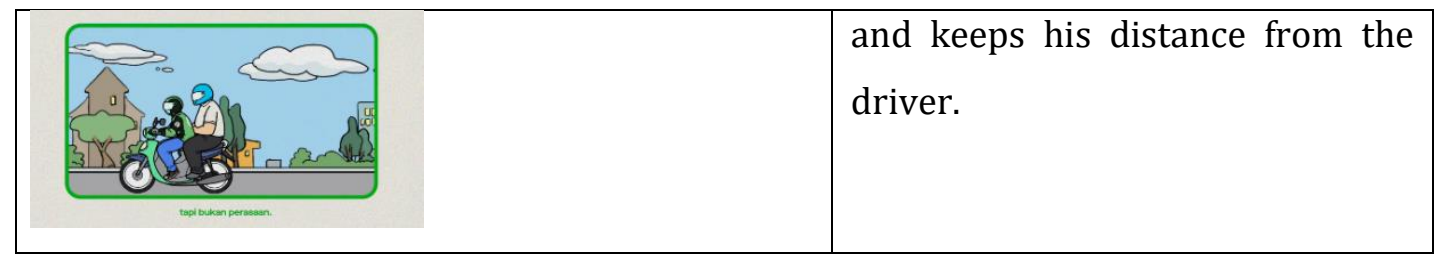

The eighth scene reflects the safety steps taken by GoRide through the driver's obligation to wear masks and recommendations for the use of gloves, the appeal for passengers to bring their own SNI helmets, to the availability of the J3K Comfort Zone for customers for safety and driving comfort. By complying with the implementation of health protocols by GoRide, one is no longer anxious when they have to carry out urgent activities outside because GoRide will always be ready to accompany passengers..

\section{Scene 9}

\begin{tabular}{|c|c|}
\hline \multicolumn{2}{|c|}{ (sign) } \\
\hline \multicolumn{2}{|c|}{$\begin{array}{l}\text { (sign) } \\
\text { Activities made easy with Gojek "J3K". }\end{array}$} \\
\hline (signifier) & (signified) \\
\hline 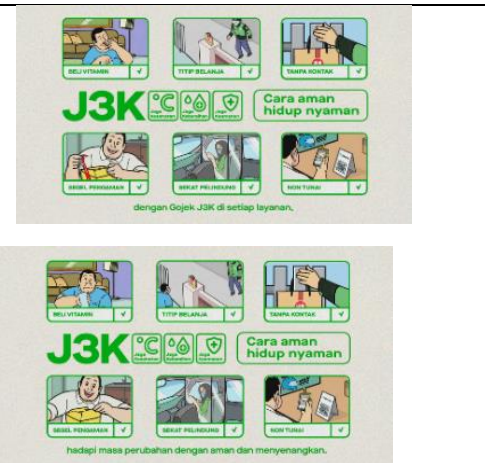 & $\begin{array}{l}\text { The conclusion from the initial } \\
\text { visualization to the end through } \\
\text { the principle of "J3K". The } \\
\text { principle of "J3K" is here to } \\
\text { accompany the public to live } \\
\text { comfortably in a safe way. }\end{array}$ \\
\hline
\end{tabular}

The last scene shown depicts a flash of the core of the "J3K" commercial. in the advertisement there are recommendations for consuming vitamins that can be accessed through GoMed, entrusting daily needs with GoMart, avoiding direct contact when shopping for GoFood by hanging on the fence, maintaining cleanliness and safety of GoFood with a safety seal to providing bulkheads in GoCar and using GoPay as a transaction solution. The actions that have been described in the entire scene provide a stimulus to the public that Gojek products can always be present together without worrying about contracting the Covid-19 disease during the pandemic. 
QAULAN, Vol. 2, No.2, Desember 2021

Debi Nur Hanifah, et. al., Marketing Strategy....

\section{CONCLUSION}

Marketing is a social and managerial process of obtaining what is needed and wanted through the creation and exchange of value with others. Advertising through various media is a form of Integrated Marketing Communications. Structurally, advertisements contain signs as a picture of material concepts and meanings in an image or illustration in constructing social reality.

Along with the development of current technology, there is an online motorcycle taxi ordering service application in the form of Gojek to help the community in carrying out their activities. Gojek is a technology company from Indonesia that serves transportation through motorcycle taxi services. During the COVID-19 pandemic, Go-Jek has a marketing strategy through advertisements for the Covid-19 prevention message service. The prevention advertisements are broadcast on various media such as YouTube and television.

Several other research literatures conducted research by taking from the point of view of the problem the influence of Gojek's advertising on consumer purchasing power. Considering that the Gojek "J3K" advertisement that was taken in this study was only launched by the Gojek company in August and coincided with the Covid-19 pandemic, so this research is expected to be able to raise something that has not been analyzed by previous researchers. The Gojek "J3K" advertisement is analyzed for each image using Ferdinand De Saussure's theory so that it is able to dismantle the meaning of the marketing strategy contained in the Gojek "J3K" advertisement in the Covid-19 prevention message

\section{REFERENCES}

Doembana, Ismawati., Abdul Rahmat, Muhammad Farhan. Buku Ajar: Manajemen dan Strategi Komunikasi Pemasaran. Yogyakarta: Zahir Publishing, 2017.

Indrawati, Komang Ayu Pradnya., Nyoman Sudiarta, Wayan Suardana. "Efektifitas Iklan melalui Media Sosial Facebook dan Instagram sebagai Salah Satu Strategi Pemasaran di Krisna Oleh-Oleh Bali," Jurnal Analisis Pariwisata, Vol. 17 No. 2 (2017). 
QAULAN, Vol. 2, No.2, Desember 2021

Debi Nur Hanifah, et. al., Marketing Strategy....

Kasali, Rhenald. Membidik Pasar Indonesia: Segmentasi, Targeting, dan Positioning. Jakarta: PT Gramedia Pustaka Utama, 2001.

Kotler, Philip. Manajemen Pemasaran, Edisi 13. Jakarta: Erlangga, 2009. and Garry Amstrong. Principles of Marketing. New Jersey: Pearson Education Limited, 2012.

Lukitaningsih, Ambar. "Iklan yang Efektif sebagai Strategi Komunikasi Pemasaran," Jurnal Ekonomi dan Kewirausahaan, Vol. 03, No. 12 (2018).

Morissan. Periklanan: Komunikasi Pemasaran Terpadu. Jakarta: Prenadamedia Group, 2010.

Piliang, Yasraf Amir. Hipersemiotika: Tafsir Cultural Studies atas Matinya Makna. Bandung: Jalasutra: 2003.

Sitorus, Onny Fitriana., Novelia Utami. Buku Ajar: Strategi Promosi Pemasaran. Universitas Muhammadiyah Prof. DR. HAMKA: Fakultas Keguruan dan Ilmu Pendidikan, 2017.

Sobur, Alex. Analisis Teks Media: Suatu Pengantar untuk Analisis Wacana, Analisis Semiotika dan Analisis Framing. Bandung: Remadja Karya, 2001.

Sugiyono. Metode Penelitian Kuantitatif, Kualitatif, dan $R$ \& D. Bandung: Alfabeta, 2016.

Syaiful, Fahmi Fadlillah., Elihami Elihami, "Penerapan Analisis SWOT terhadap Strategi Pemasaran Usaha Minuman Kamsia Boba Milik Abdullah di Tengah Pandemi Covid-19 di Kabupaten Bangkalan," Jurnal Edukasi NonFormal, Vol. 1 No. 2 (2017).

www.covid19.go.id

www.kompas.com

www.kpi.go.id

www.youtube.com 